\title{
"The economic mechanism for the formation of land rent at agricultural enterprises"
}

\author{
Dmytro Shyian iD http://orcid.org/0000-0002-0815-267X
}

AUTHORS

R http://www.researcherid.com/rid/V-1489-2017

Anatolii Moskalenko iD https://orcid.org/0000-0001-7223-6862

Kseniia Kirichenko

Dmytro Shyian, Anatolii Moskalenko and Kseniia Kirichenko (2020). The

ARTICLE INFO economic mechanism for the formation of land rent at agricultural enterprises. Economics of Development, 19(1), 35-44. doi:10.21511/ed.19(1).2020.04

DOI http://dx.doi.org/10.21511/ed.19(1).2020.04

RELEASED ON Friday, 08 May 2020

RECEIVED ON

Monday, 02 March 2020

ACCEPTED ON

Thursday, 19 March 2020

\section{(cc) EY}

LICENSE

This work is licensed under a Creative Commons Attribution 4.0 International License

JOURNAL

"Economics of Development"

ISSN PRINT 1683-1942

ISSN ONLINE 2304-6155

PUBLISHER

LLC "Consulting Publishing Company "Business Perspectives"

FOUNDER

Simon Kuznets Kharkiv National University of Economics

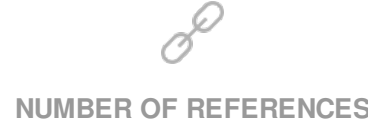

27
NUMBER OF FIGURES

5
NUMBER OF TABLES

3

(C) The author(s) 2022. This publication is an open access article. 


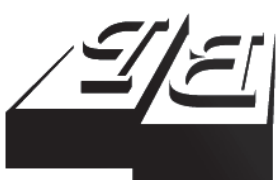

BUSINESS PERSPECTIVES

Publisher

LLC "CPC "Business Perspectives" Hryhorii Skovoroda lane, 10, Sumy, 40022, Ukraine www.businessperspectives.org

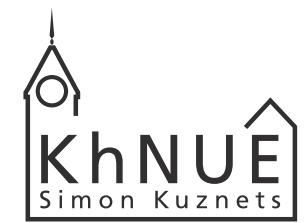

S. KUZNETS KHNUE

Founder

Simon Kuznets Kharkiv National University of Economics, Nauky avenue, 9-A, Kharkiv, 61166,

Ukraine

http://www.hneu.edu.ua/

Received on: 2nd of March, 2020 Accepted on: 19th of March, 2020 Published on: 8th of May, 2020

(C) Dmytro Shyian,

Anatolii Moskalenko,

Kseniia Kirichenko 2020

Dmytro Shyian, Doctor of Economics, Professor, Head of the Department of Enterprise Economics and Management, Simon Kuznets Kharkiv National University of Economics, Ukraine.

Anatolii Moskalenko, Doctor of Economics, Associate Professor, Director of the Institute of Agricultural Microbiology and Agro-Industrial Production, National Academy of Agrarian Sciences, Ukraine.

Kseniia Kirichenko, Ph.D. Student, Department of Enterprise Economics and Management, Simon Kuznets Kharkiv National University of Economics, Ukraine.

\section{(c) (i)}

This is an Open Access article, distributed under the terms of the Creative Commons Attribution 4.0 International license, which permits unrestricted re-use, distribution, and reproduction in any medium, provided the original work is properly cited.
Dmytro Shyian (Ukraine), Anatolii Moskalenko (Ukraine), Kseniia Kirichenko (Ukraine)

\section{THE ECONOMIC MECHANISM FOR THE FORMATION OF LAND RENT AT AGRICULTURAL ENTERPRISES}

\begin{abstract}
The current stage of land relations in the agrarian sector is characterized by significant development of lease relations. Today, these relationships are heavily influenced by competition for land tenure, leading to increased land payments. Considering this, as well as the prospects for the agricultural land market formation, the task was to assess the dependence of agricultural land rent on the intensity and economic efficiency of wheat, corn for grain, sunflower production. The research was carried out on the example of agricultural enterprises of Kharkiv region. Grouping, a graphical method was chosen as research methods. The subject of the study was also the rent dynamics for agricultural land in Kharkiv region and Iowa, the USA.

The obtained results made it possible to establish the fact that the rent value depends on the total amount of expenses, and the expenses on the articles «wages», «depreciation». It is concluded that the reasons for this may be related to the investment of these enterprises in human capital and the fixed assets that make them lease on more favorable terms for share owners. No dependence was found between the rent value on the value of the yield and the financial result on the selected crops. At the same time, there is a clear tendency that with the increase in the value of the rent, there is an increase in the ratio of its value to the value of costs and income from the crop sector. It is concluded that this can lead to a decrease in investment opportunities for the enterprises with the highest level of lease payments for agricultural land.
\end{abstract}

Keywords

land lease, land market, yield, profit, production intensity

JEL Classification

O13, Q15, Q24

Д. В. Шиян (Україна), А. М. Москаленко (Україна),

К. А. Кіріченко (Україна)

\section{ЕКОНОМІЧНИЙ МЕХАНІЗМ ФОРМУВАННЯ ОРЕНДНОЇ ПЛАТИ ЗА ЗЕМЛЮ В СІЛЬСЬКОГОСПОДАРСЬКИХ ПІДПРИЕМСТВАХ}

\section{Анотація}

Сьогоднішній етап розвитку земельних відносин в аграрному секторі характеризується значним розвитком орендних відносин. Ці відносини сьогодні перебувають в значній мірі під суттєвим впливом конкуренції за право оренди землі, що призводить до зростання плати за землю. Виходячи з цього, а також з перспектив формування ринку сільськогосподарської землі було поставлено завдання здійснити оцінку залежності орендної плати за землю сільськогосподарського призначення від рівня інтенсивності та економічної ефективності виробництва пшениці, кукурудзи на зерно, соняшнику. Дослідження здійснювалось на прикладі сільськогосподарських підприємств Харківської області. В якості методів дослідження було обрана групування, графічний метод. Об’єктом дослідження виступала також динаміка орендної плати за землі сільськогосподарського призначення в Харківській області та штаті Айова США.

Отримані результати дали можливість встановити, що величина орендної плати знаходиться в залежності від загальної величини витрат, та витрат по статтям «оплата праці», «амортизація». Робиться висновок, що причини цього можуть бути пов'язані з інвестуванням даних підприємств в людський капітал та основні засоби, що змушують їх укладати договори оренди на більш сприятливих умовах для власників паїв. Не було встановлено залежності рівня орендної плати з величиною урожайності та фінансовим результатом по обраним культурам. 
В той же саме час має місце чітка тенденція, що з зростанням величини орендної плати відбувається зростання співвідношення іiі величини $з$ величиною витрат та доходів від галузі рослинництва. Робиться висновок, що у підприємств з найбільшим рівнем плати за оренду землі сільгосппризначення це може призводити до зменшення їх інвестиційних можливостей.

Ключові слова оренда землі, ринок землі, урожайність, прибуток, інтенсивність виробництва

Класифікація JEL O13, Q15, Q24

\section{INTRODUCTION}

The present stage of rural economic development is largely characterized by leasing-related processes. First and foremost, it concerns the land. Land reform, which has been ongoing in Ukraine since the early 1990s, has actually created a new class of land share owners. In early 2018 there were an estimated $6.9 \mathrm{mln}$ of them. Today, the country folk receive a large share of their income precisely in the form of rent for land shares. In addition, increasing competition for leaseholder forces producers to improve efficiency in order to be able to fulfill their obligations to employers. In addition, increasing competition for leaseholder forces manufacturers to increase production efficiency in order to be able to fulfill their obligations to employers.

However, now land leasing issues also have important scientific and practical aspects. In particular, the question of the rent value impact on the investment development of enterprises, the production structure, and the employment level in rural areas needs further investigation.

\section{LITERATURE REVIEW}

Today, the problem of leasing relations in agriculture is the focus of agrarian economic science in Ukraine. The works of Dobryak (2004), Zos-Kior (2015), Malik (1993), Martin (2011), Koshkalda (2011), Stupen (2018), Tretiak (2004, 2008), Fedorov (2011), Khodakivska (2016), Shary (2013), Shebanina (2011), Shpychak $(2001,2018)$ and others are devoted to this problem.

A wide range of issues concerning land tenure are discussed. In particular, this relates to the interdependence between the amount of rent and the factors that affect its value. Thus, Moskalenko (2013), having carried out research on the example of agricultural enterprises in Polissia region, has concluded that larger agricultural land owners, as a rule, pay higher rent due to higher yields of cereals and sunflower. Moreover, it has been established that these enterprises also have a smaller share of the livestock sector in the structure of marketable products. Savarina (2010) made it clear that a rent increase of up to 5\% would lead to a profitability level of around $9.8 \%$.

It is noted that in the developed countries, agricultural land rental markets are quite stable. According to Melnyk, Makarenko (2012), in the process of land turnover, the share of sales and purchase operations averages 1-3\% of their area. In many countries, this may fluctuate. In the US and Ireland, it is $1.2 \%$, the UK, France and Italy - 2.0\%, Germany, Holland, Belgium - 1.5-2.5\%, in Denmark - about 4\% of the total value of the land fund. In addition, the vast majority of countries have significant restrictions on the size of land that can be owned by one person. According to the data provided by Loiko (2017), in Hungary and Lithuania, the maximum land area per person is 300 hectares, in Romania - 200 hectares, in Japan - 3 hectares, Denmark - 150 hectares. There are also restrictions on the area of agricultural land that can be rented by one person. In particular, in Hungary the maximum area of land that can be rented by one person is 2500 hectares, in Denmark - 150 hectares, in France - 200 hectares. Such market regulation for the sale and lease of agricultural land practically makes it impossible to generate speculative capital and minimizes the distance between owners and rural communities. Unfortunately, nowadays in Ukraine, the absence of such restrictions, in many cases is one of the factors that creates political problems and social tension around the problem of land market introduction. In addition, as noted by Yukhymenko, Zagursky (2010), a major drawback of modern lease relations from their point of view, is the prevailing short-term lease agreements, which do not create motivation to care for the land in their leaseholders, prevent its depletion on the basis of shortterm monocultural agriculture. 
Kalyuzhny (2002) addressed this problem in 2002. He believed that the lease term should be at least five to seven years in order to ensure that the lease relations were combined with the processes of investment and greening of production. This problem actually occurred 8-10 years ago. However, according to Zhytomyr region, cited by Loiko (2019), already in 2018, 80.5\% of leases were concluded for a period of 7 years or more, whereas in 2014 their share was equal to only $16.9 \%$.

From the point of view of Berezivska (2013), land lease also has another advantage over its purchase - it makes it impossible to further subdivide the land and therefore maintain a sufficient level of production concentration. Andriichuk (2017) raises the issue of a relationship between the enterprise size and rent. From his point of view, the monopolization of land rent in agriculture is a real threat that requires state intervention. The author also believes that the methodological approach to determining the size of leased land should be based on the principle of granting the right to lease only as much land as the agricultural production association needs to provide raw materials for its own production capacity. However, in this case, the question is who should make such calculations and whether they will entail an increase in corruption in public authorities?

Foreign authors also pay considerable attention to issues related to agricultural land leases. Thus, Soule, Tegene, Wiebe (2000), analyzing data from 941 corn producers in the USA, conclude that leaseholders with longer leases are more responsible for environmental measures. An analysis of farm performance on the example of Poland was made by Latruffe, Balcombe, Davidova, and Zawalinska (2005). In this case, all enterprises were divided on the basis of their specialization in plant and animal production. The authors conclude that the scale effect has an impact on the enterprises' level of efficiency. In addition, livestock enterprises use the agricultural land more efficiently. In their opinion, this factor should be taken into account in the development of legislative acts regarding land lease and state support for agricultural enterprises.

It should be noted that in the long run, the effectiveness of agrarian policy, including the land reform in the state, will be determined by the level of social protection of the rural population and the development of rural territories. That is why the current stage of land reform, including land leasing issues, should be aimed at achieving the strategic goals of the state - sustainable development of rural areas, termination of their depopulation and improving the use of agricultural land.

\section{AIMS}

The purpose of the study is to analyze the dynamics and dependence of the rent level on the intensity and economic efficiency of major crops production in agricultural enterprises of Kharkiv region.

\section{METHODS}

The study was conducted based on 2018 statistics of agricultural enterprises in Kharkiv region, acting as leaseholders of agricultural land. There were 521 enterprises. When the boundaries of groups of enterprises were determined, they were checked for compliance with the law of normal distribution. To evaluate in detail the obtained results, use the graphical method of displaying the established dependencies with the determination of regression parameters, coefficients of determination. There was a grouping of enterprises according to the level of rent with the division into six groups. A large number of businesses have produced reliable results. To analyze the dynamics of rent change, Iowa State data for 1999-2018 and Kharkiv region for 2010-2018 were used.

\section{RESULTS}

To start with, we look at the dynamics of changing the rent value in both Ukraine, and one of the US states, namely Iowa. The choice of this state is due to the fact that it is the leading agricultural state in the US in the production of pork, eggs and a number of farms per inhabitant. In addition, natural climatic conditions of this state are similar to the natural conditions of Kharkiv region. In particular, their latitude does not significantly differ. 
Figure 1 shows the dynamics of rent changes per acre of agricultural land in Iowa for the period 1999-2018. During the period under review, the rent increased from $\$ 112$ to $\$ 230$ / acre, or 2.1 times. At the same time, since 2012 the price of land lease has stabilized. Moreover, compared to 2015, in 2018 it even decreased by $\$ 30 /$ acre. Thus, today there is a relative stabilization of agricultural land price in the United States.

The dynamics of rent in agricultural enterprises in Kharkiv region has been analyzed. At the same time, in order to be able to compare the data with the State of Iowa, the amount of rent was translated into US dollars based on the average rate of UAH / USD for each year. The period covered 2010-2018. Unfortunately, it was not possible to obtain information for a longer period. Statistical reporting of agricultural enterprises was used to determine the rent.The data in Figure 2 make it possible to assess the nature of the rent change.

First of all, it should be noted that the rent is given per hectar of arable land, not per acre as in Iowa. Based on the fact that one hectare is approximately 2.47 acres, it can be concluded that the absolute value of rent in Iowa in different years was approximately 8-10 times greater than in Kharkiv region.

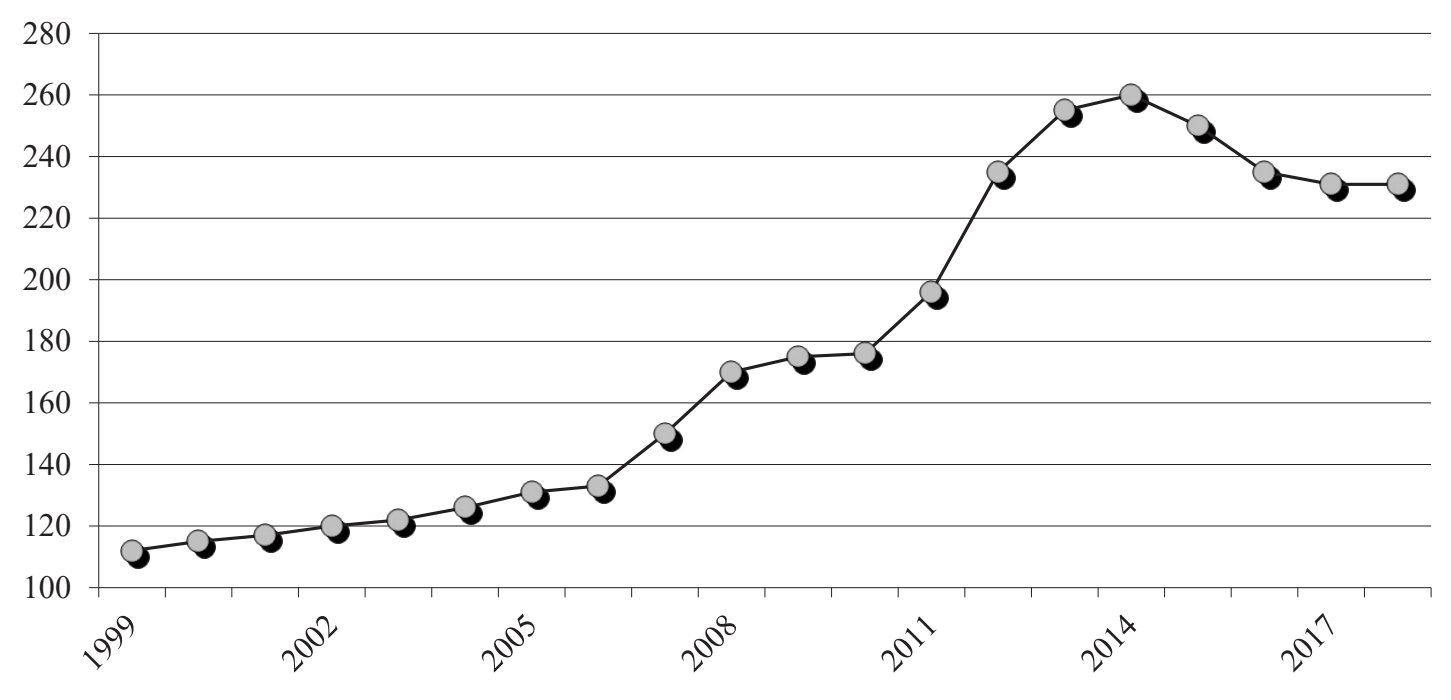

Source: Compiled by the authors based on the data (USDA, 2020; Statistics by Subject, 2020, pp. 26).

Figure 1. The dynamics of rent in Iowa in 1999-2018, USD / acre

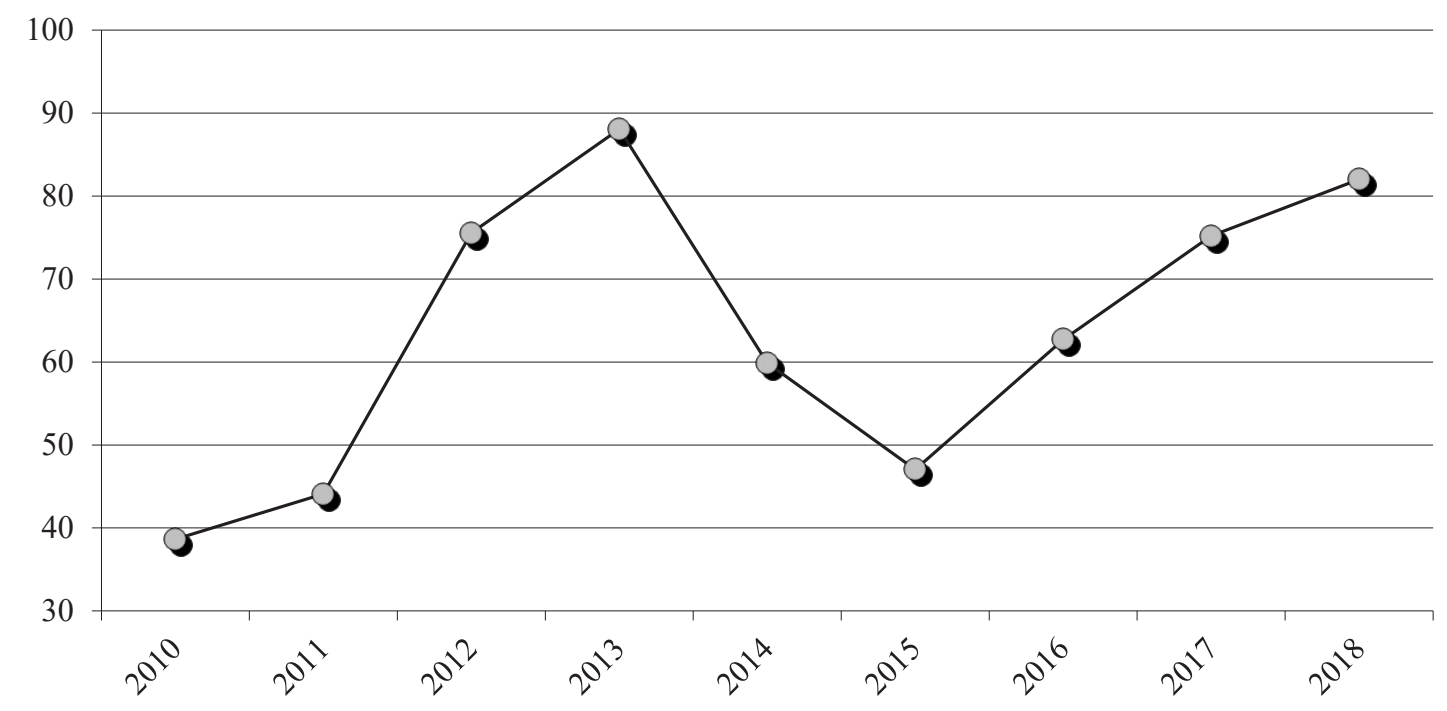

Source: Compiled by the authors based on the data of the State statistics committee.

Figure 2. Dynamics of rent per a hectare of arable land in Kharkiv region in 2010-2018, USD / ha 
Absolute value of rent in Iowa in different years was approximately 8-10 times greater than in Kharkiv region. This indicates that the level of rents in Ukraine can potentially increase even more. Regarding the tendency of change in the land lease value, in this case there are two periods. The first one covers the years $2010-2015$ and is characterized by a gradual increase in the rent until 2013 inclusive. In 2013, rents peaked at $\$ 88$ / ha. However, the sharp fall in the hryvnia in 2014 also led to a fall in the US dollar rent. In 2015, it reached a minimum of $\$ 47$ / ha. Since 2016, a new period has begun, characterized by an increase in the level of rent. It peaked in 2018 at $\$ 82 /$ ha.

Thus, during 2016-2018 the main trend was the increase in the rent value. This is largely due to the expectations of business entities about the introduction of the agricultural land market. In addition, the competition level for land use rights between agricultural enterprises is increasing, which is also causing land prices to rise. On the whole, it can be stated that, based on the above data, the tendencies in the change of the lease price of agricultural land in Ukraine are multifaceted and largely related to the macroeconomic situation.

The next stage of the study was to analyze the dependence of the rent on the level of intensity and economic effi-ciency of individual crops production. The three most important crops were selected for Kharkiv region: wheat, corn for grain and sunflower. As of 2018, these three crops occupied $79.0 \%$ of arable agricultural enterprises area of the region. In total there were 521 enterprises. Table 1 shows the results of agricultural enterprises grouping by the level of rent per 1 ha of arable land.

Table 1. Impact of individual crops production costs on the value of rent per 1 ha of arable land in agricultural enterprises of Kharkiv region in 2018

Source: Compiled by the authors according to the statistics of agricultural enterprises.

\begin{tabular}{|c|c|c|c|c|c|c|c|}
\hline \multirow{2}{*}{$\begin{array}{c}\text { Costs per } 1 \text { ha of cultivated } \\
\text { area, UAH }\end{array}$} & \multicolumn{7}{|c|}{ Groups of enterprises for rent, UAH / ha } \\
\hline & Up to 750 & $750.1-1.500$ & $\begin{array}{l}1500.1- \\
2.250\end{array}$ & $\begin{array}{l}2250.1- \\
3.000\end{array}$ & $\begin{array}{c}3000.1- \\
3.750\end{array}$ & Over 3.750 & $\begin{array}{l}\text { In the } \\
\text { regione }\end{array}$ \\
\hline Wheat: total & 9.862 & 11.049 & 12.333 & 12.841 & 13.540 & 15.371 & 12.491 \\
\hline Wages & 467 & 340 & 710 & 557 & 793 & 1.120 & 626 \\
\hline for depreciation & 769 & 749 & 966 & 1.128 & 837 & 1.952 & 995 \\
\hline Corn for grain: total & 14.188 & 14.592 & 14.799 & 16.341 & 19.078 & 17.593 & 16.140 \\
\hline Wages & 738 & 552 & 805 & 722 & 953 & 1.233 & 796 \\
\hline For depreciation & 658 & 1.288 & 1.180 & 1.438 & 1.421 & 1.974 & 1.349 \\
\hline Sunflower: total & 11.883 & 20.276 & 15.311 & 16.740 & 16.865 & 16.128 & 16.598 \\
\hline Wages & 754 & 1.312 & 1.321 & 1.412 & 1.024 & 2.061 & 1.320 \\
\hline For depreciation & 540 & 495 & 839 & 706 & 966 & 1.007 & 756 \\
\hline
\end{tabular}

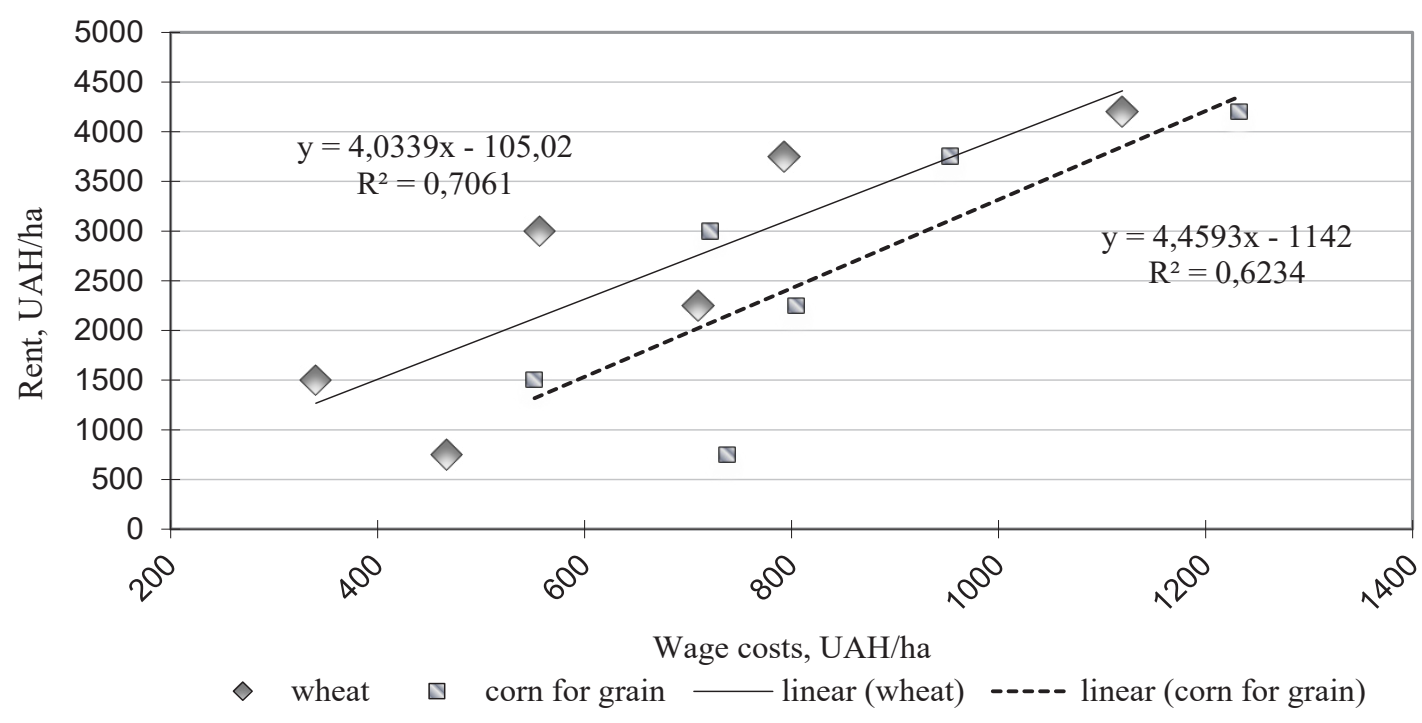

Source: Compiled by the authors according to the statistics of agricultural enterprises.

Figure 3. Relationship between the wage costs per 1 ha of wheat and corn for grain and rent for 1 ha of arable land in agricultural enterprises of Kharkiv region in 2018 (data grouped) 


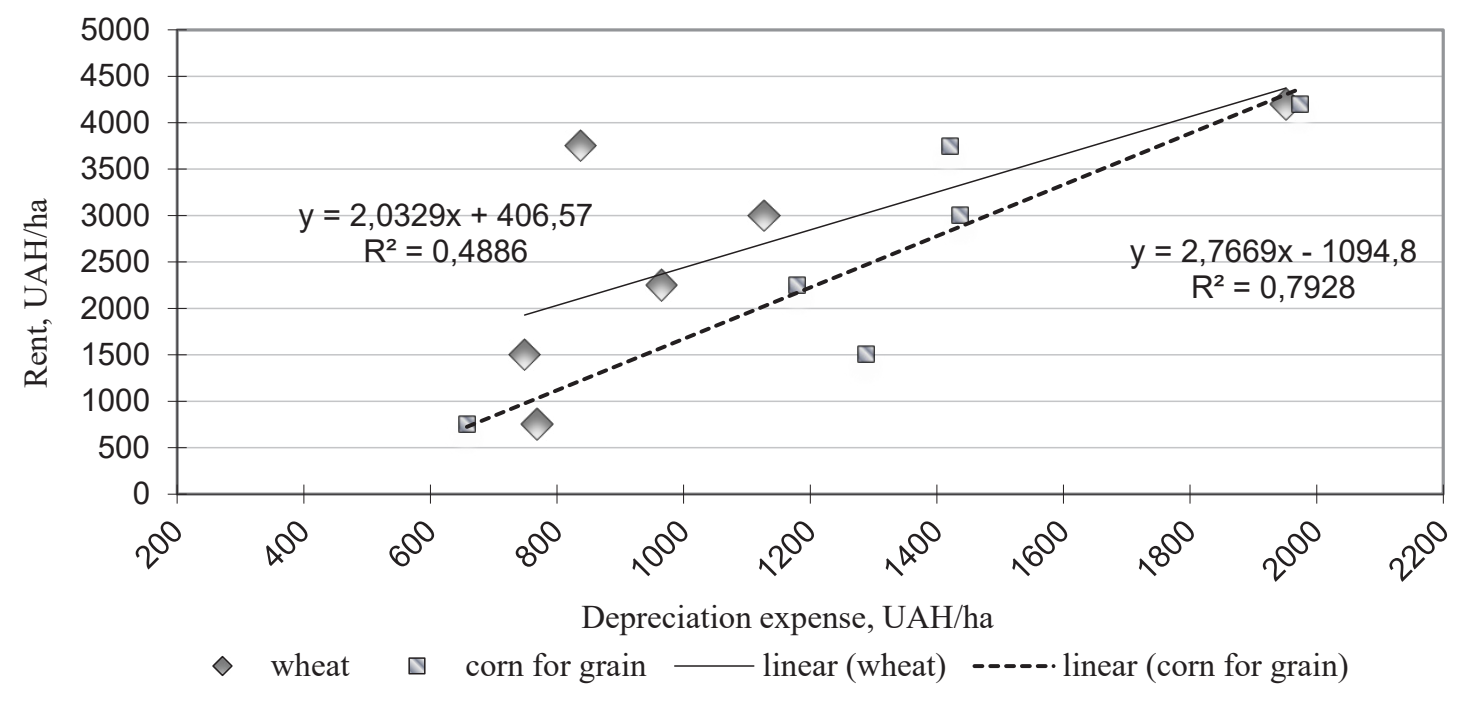

Source: Compiled by the authors according to the statistics of agricultural enterprises.

Figure 4. Dependence between the amount of depreciation per 1 ha of sown wheat and corn for grain and the amount of rent per 1 ha of arable land in agricultural enterprises of Kharkiv region in 2018 (data grouped)

First and foremost, the fact that across all three crops there is a relationship between the cost of 1 acreage and the rent per 1 ha of arable land, draws our attention. For enterprises with a large rent up to $750 \mathrm{UAH} / \mathrm{ha}$, the average cost per 1 ha of acreage was equal to 9.862 UAH for wheat, $14.188 \mathrm{UAH}$ for corn and 11.883 UAH for sunflower. In the group of enterprises with the value of rent 2,250.1-3.000 UAH / ha, the costs of these crops were already equal respectively: 12.841 UAH / ha, 16.341 UAH / ha and 16.740 UAH / ha. In the latter group with the highest level of rent the cost of wheat and corn for grain was slightly higher than in the above group, and it was lower for sunflower. At the same time, the relationship between rent and individual cost items has been much clearer. In this case, two items were selected: remuneration and depreciation. It is through these cost items that the highest level of wheat and corn relationship has been established (Figure 3 and 4). It should be noted separately that the level of correlation between rent and depreciation costs was average $\left(R^{2}=0.4886\right)$. A similar situation was with sunflower.

According to the given culture in the group with the amount of rent up to $750 \mathrm{UAH} /$ ha wages payment per 1 ha was equal to $754 \mathrm{UAH} / \mathrm{ha}$, depreciation costs - $540 \mathrm{UAH} / \mathrm{ha}$, in the group with the amount of rent 2,250.1 $3.000 \mathrm{UAH} /$ ha respectively $1.412 \mathrm{UAH} /$ ha and $706 \mathrm{UAH} /$ ha, in the group with the rent over UAH 3.750 / ha - UAH 2.061 / ha and UAH 1.007 / ha, respectively. What can such dependencies indicate?

First, the increase in the costs of the article "wages» indicates that the level of remuneration at the enterprises with higher rents is higher. Today, unfortunately, statistics does not allow us to estimate the level of labor costs per hectare or 1 quintal. At the same time, with a high degree of probability, it can be argued that the increase of expenses is not due to an increase in the amount of labor costs, but because of an increase in the level of wages. The proof of this is expenses on the article "depreciation». Its increase makes it possible to argue that enterprises with higher levels of arable land costs also have more modern machinery that requires skilled labor. The combination of these indicators explains the established pattern. However, the question remains: how it relates to the rent value. From our point of view, the increase in costs under these articles shows the desire of business owners to invest in both human capital, and fixed assets. This policy, in turn, also requires a stable lease relationship, forcing leaseholders to pay higher rents.

The next stage of the analysis was to investigate the relationship between the rent value and the production performance indicators of the three selected crops (Table 2). Analyzing the above data, we should, first of all, note the fact that for all three crops the yield remained relatively stable from group to group. Moreover, in the corn for grain in the first group, with the lowest rent, the yield was the highest. This result was unexpected for us, given that the level of costs per 1 ha tended to increase according to Table 1. Its interpretation may be due to the fact that 
these costs were not sufficiently effective in the respective enterprises and did not allow to increase the yield level. At the same time, in terms of profit, the situation was different. The profit value for wheat did not change signifi-cantly in all groups except the latter, where it was higher than the regional average. For corn, the highest value of profits was at the enterprises of the first group with the smallest amount of rent. At the enterprises with the level of rent of 1.500,1-2.250 UAH / ha, it was the lowest. One of the possible reasons for this may be the increase in costs. The corresponding decrease in profits is due to the increase in rent. For sunflower and wheat, the largest value of profits was found at the enterprises of the last group (Figure 5).

Table 2. Influence of the production efficiency level of individual crops on the amount of rent per 1 ha of arable land at the agricultural enterprises of Kharkiv region in 2018

Source: Compiled by the authors according to the statistics of agricultural enterprises.

\begin{tabular}{|c|c|c|c|c|c|c|c|}
\hline \multirow[b]{2}{*}{ Index } & \multicolumn{7}{|c|}{ Groups of enterprises for rent, UAH / ha } \\
\hline & Up to 750 & 750.1-1.500 & $\begin{array}{c}1.500,1- \\
2.250 \\
\end{array}$ & $\begin{array}{c}2.250,1- \\
3.000 \\
\end{array}$ & $\begin{array}{c}3.000,1- \\
3.750\end{array}$ & Over 3.750 & $\begin{array}{l}\text { In the } \\
\text { region }\end{array}$ \\
\hline \multicolumn{8}{|l|}{ Wheat: } \\
\hline Yield, quintal / ha & 34.7 & 33.2 & 33.8 & 34.5 & 35.8 & 35.6 & 34.3 \\
\hline Profit, UAH / ha & 3.839 & 3.839 & 3.916 & 3.585 & 3.824 & 4.669 & 3.813 \\
\hline \multicolumn{8}{|l|}{ Corn for grain: } \\
\hline Yield, quintal / ha & 71.2 & 58.1 & 61.5 & 60.3 & 67.2 & 66.8 & 62.6 \\
\hline Profit, UAH / ha & 10.575 & 6.571 & 4.152 & 4.462 & 6.409 & 7.358 & 5.707 \\
\hline \multicolumn{8}{|l|}{ Sunflower: } \\
\hline Yield, quintal / ha & 31.3 & 37.4 & 28.0 & 27.2 & 28.1 & 28.8 & 29.6 \\
\hline Profit, UAH / ha & 11.269 & 11.545 & 7.792 & 6.069 & 7.143 & 16.447 & 8.369 \\
\hline
\end{tabular}

For enterprises with lease rates from UAH 1.500 / ha to UAH 3.750 / ha, the profit margin was much smaller than in other groups. These groups comprise approximately $2 / 3$ of all enterprises, that is, the bulk of them. The decline in sunflower yields may also be related to the increase in rents. These data indicate that the change in income has no clear relationship with the change in rent. Businesses are actually investing in land leases by reducing the financial result.

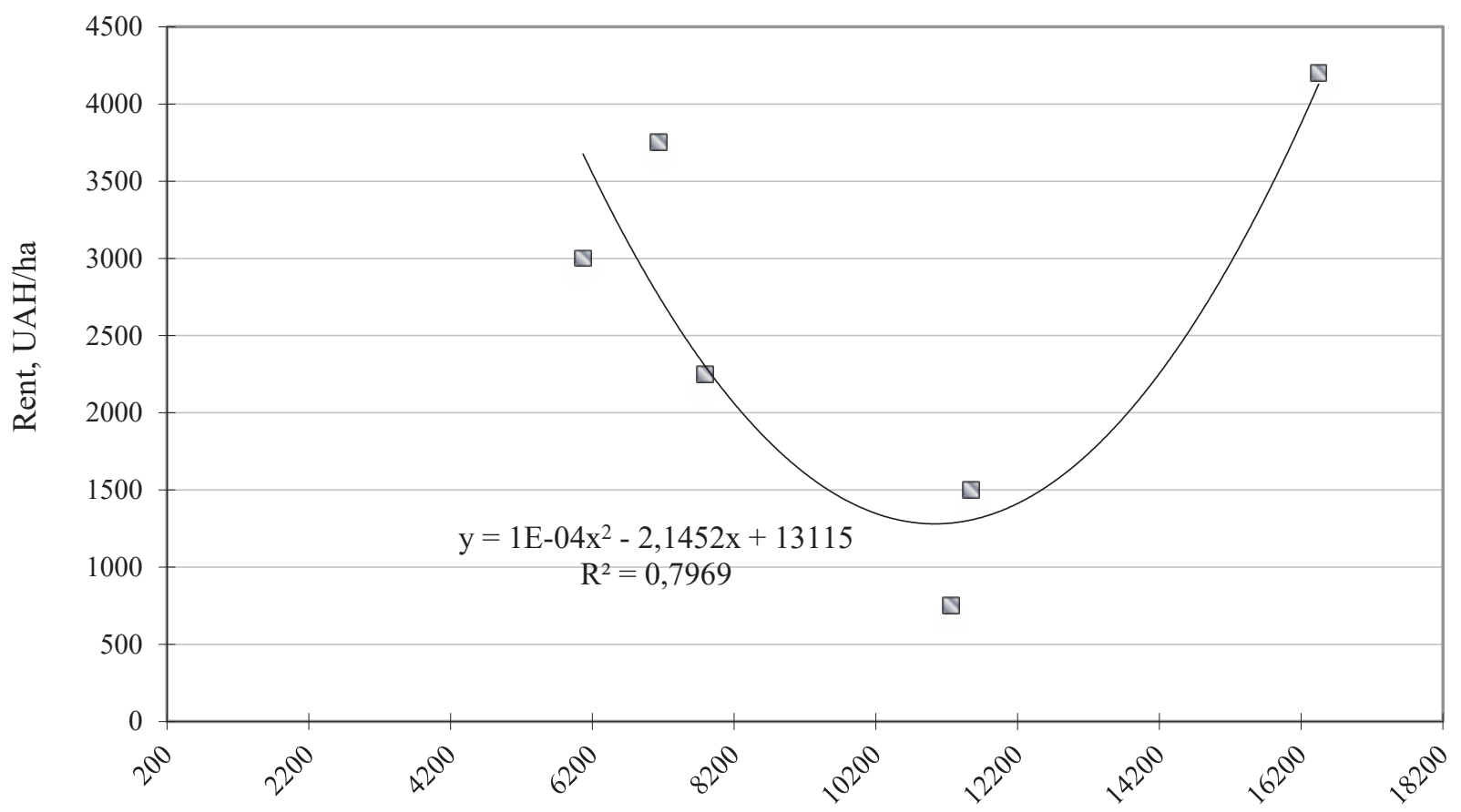

Profit, UAH/ ha

Source: Compiled by the authors according to the statistics of agricultural enterprises.

Figure 5. Relationship between profit value per 1 sowing area and rent for tha of arable land at the agricultural enterprises of Kharkiv region in 2018 (data grouped) 
In order to verify this assumption, we have analyzed the dependence of the rent on the level of expenditures and income in the crop sector. In addition, the effect of the arable land as a factor in the size of the enterprise on the value of rent was also studied.

Table 3. Dependence of rent on expenses, income and size of enterprises in Kharkiv region in 2018

Source: Compiled by the authors according to the statistics of agricultural enterprises.

\begin{tabular}{|c|c|c|c|c|c|c|c|}
\hline \multirow[b]{2}{*}{ Index } & \multicolumn{7}{|c|}{ Groups of enterprises for rent, UAH / ha } \\
\hline & Up to & $\begin{array}{l}750.1- \\
1.500\end{array}$ & $\begin{array}{l}1.500,1- \\
2.250\end{array}$ & $\begin{array}{l}2.250,1- \\
3.000\end{array}$ & $\begin{array}{l}3.000,1- \\
3.750\end{array}$ & $\begin{array}{l}\text { Over } \\
3.750\end{array}$ & $\begin{array}{l}\text { In the } \\
\text { region }\end{array}$ \\
\hline Arable land, ha & 1.716 & 1.490 & 1.892 & 2.205 & 2.396 & 1.161 & 1.887 \\
\hline $\begin{array}{l}\text { Commodity crop production per } 1 \text { ha of } \\
\text { arable land, UAH }\end{array}$ & 17.654 & 19.122 & 14.334 & 15.353 & 16.970 & 15.336 & 15.938 \\
\hline $\begin{array}{l}\text { The share of rental costs in the total value of } \\
\text { the costs in the crop industry, \% }\end{array}$ & 4.3 & 11.0 & 24.0 & 30.8 & 40.5 & 50.6 & 26.7 \\
\hline $\begin{array}{l}\text { The share of rental costs in commodity } \\
\text { products of the crop sector, \% }\end{array}$ & 1.8 & 6.0 & 13.4 & 16.8 & 19.3 & 27.3 & 14.2 \\
\hline $\begin{array}{l}\text { Share of crop production costs in the } \\
\text { structure of expenditures on agricultural } \\
\text { products, \% }\end{array}$ & 77.3 & 90.4 & 78.6 & 73.3 & 85.8 & 73.7 & 79.1 \\
\hline
\end{tabular}

The first conclusion that can be drawn from the above data is the fact that the size of the business, which in this case is characterized by arable land, does not have a clear relationship with the rent. Moreover, in the latter group of enterprises with the highest level of rent the average arable land was much smaller. Thus, the view that larger companies are able to pay a larger amount of rent does not find confirmation according to the statistics of Kharkiv region. The value of crop products, in this case, in different groups of the studied enterprises remained relatively stable. Accordingly, the value of crop products sales cannot be a source for rent formation.

Two other relative indicators allow us to estimate the relationship between the rent and the level of income and crop production expenses per 1 ha of arable land. In this case, we have the following dependence: the increase in the lease value leads to an increase in its share in relation to both the costs of the crop, and commodity industries. Its share in relation to commodity products at the enterprises of the first group with the level of rent up to $750 \mathrm{UAH} /$ ha was equal to $1.8 \%$, and to the expenses - $4.3 \%$, while at the enterprises with the value of rent 2.250,1-3.000 UAH / ha these indicators were already equal to $16.8 \%$ and $30.8 \%$, respectively, and for enterprises with rents over UAH 3.750 / ha $-27.3 \%$ and 50.6\%. In the latter group, virtually half of all costs are related to land rent. The obtained data, in turn, can explain the lack of correlation between the cost level and yield. The absence of rising costs for high-rent businesses is due to the fact that a significant amount of these costs are related to land rents and, therefore, cannot be a source of increased crop yields.

In order to check whether the livestock production acts as a source of additional rent formation, we evaluated the share of the crop industry expenses in the structure of expenses in the agricultural production. It has been found that there is no significant difference in this indicator, for example, between the group with the level of costs up to $750 \mathrm{UAH} /$ ha and more than $3.750 \mathrm{UAH} / \mathrm{ha}$. Thus, at the enterprises of the first group the magnitude of this indicator was $77.3 \%$, at the enterprises of the second group $-73.7 \%$. Therefore, rent is a significant factor in influencing profit margins and spending levels at agricultural enterprises.

\section{CONCLUSION}

The research conducted on the example of agricultural enterprises in Kharkiv region has made it possible to establish correlation between the level of production intensity of wheat, corn for grain, sunflower and the level of rent. This dependence was particularly clearly stated in terms of labor costs and depreciation per 1 ha of the acreage of these crops. At the same time, there were no clear patterns between the level of production efficiency and rent. It has been suggested that the decrease in the profit level in individual groups in the production of sunflower and corn for grain may be due precisely to the increase in the level of rent. However, this hypothesis needs further 
validation. In addition, due to the lack of information, it was not possible to investigate the impact of the quality and location of agricultural land on the rent value.

A correlation has been found between the amount of rent and the total amount of expenses, revenues from the crop sector. In the group of enterprises with the highest level of rent there is a significant influence of its value on the formation of the general level of expenses. A considerable part of the income (27.3\%) from the sale of crop production in this group of enterprises goes to the payment of land rent.

It can be summarized that the increase in the value of rent is largely determined by the market and the leaseholders' desire to obtain guarantees of land tenure in order to minimize the risk to future production activities. As a result, businesses paying significant rents, substantially limit investment opportunities. This can create strategic threats for them in terms of economic security.

\section{AUTHOR CONTRIBUTIONS}

Conceptualization: Dmytro Shyian.

Data curation: Dmytro Shyian, Anatolii Moskalenko.

Formal analysis: Dmytro Shyian, Anatolii Moskalenko.

Funding acquisition: Dmytro Shyian, Anatolii Moskalenko.

Methodology: Dmytro Shyian, Anatolii Moskalenko.

Resources: Anatolii Moskalenko.

Software: Kseniia Kirichenko.

Visualization: Kseniia Kirichenko.

Writing - original draft: Dmytro Shyian, Anatolii Moskalenko.

Writing - review \& editing: Anatolii Moskalenko, Kseniia Kirichenko.

\section{REFERENCES}

1. Andriichuk, V., \& Sas, I. (2017). Methodological approaches to definition of the land use limits in terms of threat of monopolization of the land lease market. The Economy of Agro-Industrial Complex, 8, 22-33. (In Ukrainian). Retrieved from http://eapk.org.ua/en/contents/2017/08/22

2. Berezivska, O. (2013). The economic regulation of functioning of agricultural enterprises on the basis of land lease. The Economy of AgroIndustrial Complex, 6, 96-102. (In Ukrainian). Retrieved from http://eapk.org.ua/en/contents/2013/06/96

3. Dobrjak, D., Tykhonov, A., \& Palamarchuk, L. (2004). Ekonomichnyj oborot zemli v Ukrajini: teorija, metodologhija i praktyka [Economic Land Turnover in Ukraine: Theory, Methodology and Practice] (136 p.). Kyiv: Urozhaj. (In Ukrainian)

4. Fedorov, M. (2011). Zemelna reforma i rozvytok rynkovykh zemelnykh vidnosyn [Land reform and development of market land relations]. The Economy of Agro-Industrial Complex, 7, 55-60. (In Ukrainian). Retrieved from http://eapk.org.ua/sites/default/files/ eapk/2011/2011_07/11_07_06.pdf

5. Yukhymenko, O., \& Zahurskyi, O. (2010). Rozvytok orendnykh vidnosyn v ahrarnomu sektori ekonomiky [Development of lease relations in the agricultural sector of the economy]. The Economy of Agro Industrial - Complex, 1, 18-21. (In Ukrainian)

6. Kaljuzhnyj, M. (2002). Land lease term as a factor of its effective use [Stroky doghovoriv orendy zemli jak faktor efektyvnosti yii vykorystannja]. Visnyk Kharkivskoho natsionalnoho ahrarnoho universytetu - Bulletin Kharkiv National Agrarian University, 7, 60-68. (In Ukrainian)

7. Khodakivska, O. (2016). Features of rent of state-owned land regulation. The Economy of Agro-Industrial Complex, 6, 49-58. (In Ukrainian). Retrieved from http://eapk.org.ua/en/contents/2016/06/49

8. Koshkalda, I. (2011). Rentnyi faktor u systemi orendnykh vidnosyn [Rental factor in rental relations system]. AghroSvit - Agro-world, 24, 20-24. (In Ukrainian). Retrieved from http://www.agrosvit.info/?op=1\&z=788\&i=4

9. Latruffe, L., Balcombe, K., Davidova, S., \& Zawalinska, K. (2005). Technical and scale efficiency of crop and livestock farms in Poland: does specialization matter? Agricultural Economics, 32, 281-296. http://dx.doi.org/10.1111/j.1574-0862.2005.00322.x

10. Lojko, S. (2017). World experience of market circulation of lands. The Economy of Agro-Industrial Complex, 5, 91-96. (In Ukrainian). Retrieved from http://eapk.org.ua/en/contents/2017/05/91

11. Lojko, S. (2019). Lease land relations in the agriculture of Zhytomyr region. The Economy of Agro-Industrial Complex, 1, 89-95. (In Ukrainian). Retrieved from http://eapk.org.ua/en/contents/2019/01/89

12. Malik, M. (1993). Orenda i orendni vidnosyny [Rent and lease relations]. In P. Sabluka, \& V., Meselj-Veseljaka. Rozvytok form hospodariuvannia na seli [Development of forms of farming in the countryside] (pp. 163-175). Kyiv: Urozhaj. (In Ukrainian)

13. Martyn, A. (2011). Problems of rental relations in agricultural land use. Zemlevporjadnyj visnyk - Land management newsletter, 9, 18-25. (In Ukrainian) 
14. Melnyk, L., \& Makarenko P. (2012). Naukovi aspekty rynku zemel [Scientific aspects of the land market]. The Economy of Agro-Industrial Complex, 9, 10-15. (In Ukrainian). Retrieved from http://eapk.org.ua/sites/default/files/eapk/2012/2012_09/12_09_02.pdf

15. Moskalenko, A. (2013). Features of Rental Charge Formation in Agricultural Enterprises of Polissya Area. The Economy of Agro-Industrial Complex, 12, 19-25. (In Ukrainian). Retrieved from http://eapk.org.ua/en/contents/2013/12/19

16. Savarina, I. (2010). Formuvannja orendnoji platy za majno ta zemlju v reghioni [Formation of rent for property and land in the region]. The Economy of Agro-Industrial Complex, 10, 18-21. (In Ukrainian). Retrieved from http://eapk.org.ua/sites/default/files/ eapk/2010/2010_10/10_10_03.pdf

17. Sharyj, Gh. (2013). Ekonomichnyj obigh zemelj siljsjkoghospodarsjkogho pryznachennja: stan ta perspektyvy [Economic circulation of agricultural land: status and prospects]. Zemlevporjadnyj visnyk - Land Use Bulletin, 9, 4-8. (In Ukrainian)

18. Shebanina, O. (2008). Orendni zemelni vidnosyny: suchasnyi stan ta osnovni napriamy udoskonalennia [Land lease relations: current state and main directions of improvement]. The Economy of Agro-Industrial Complex, 7, 7-13. (In Ukrainian). Retrieved from https://www. mnau.edu.ua/files/faculty/men/kaf_kibernetuku/shebanina/2008-shebanina-ozv.pdf

19. Shpychak, O. (2018). Price levels of agricultural lands as a background for their effective market functioning. The Economy of Agro-Industrial Complex, 3, 38-48. (In Ukrainian). Retrieved from http://eapk.org.ua/en/contents/2018/03/38

20. Shpychak, O. (2001). The problem of land reform and the price of agricultural land [Problema zemeljnoji reformy i ciny zemli siljsjkoghospo-darsjkogho pryznachennja]. Naukovyj visnyk NUBiP. 68, 10-17. (In Ukrainian)

21. Soule, M., Tegene, A., \& Wiebe, K. (2000). Land Tenure and the Adoption of Conservation Practices. American Journal of Agricultural Economics, 82, 993-1005. http://dx.doi.org/10.1111/0002-9092.00097

22. Stupen, R. (2018). Status and features of market turnover of agricultural land in Ukraine. AghroSvit - Agro-world, 23, 3-9. (In Ukrainian). Retrieved from http://www.agrosvit.info/?op $=1 \& \mathrm{z}=2769 \& \mathrm{i}=0$

23. Stupen, R. (2018). Rynok zemelj siljsjkoghospodarsjkogho pryznachennja v Ukrajini: stan ta perspektyvy rozvytku [Agricultural Land Market in Ukraine: Status and Prospects for Development] (304 p.). Kyiv: DKS-Centr. (In Ukrainian)

24. Tretiak, A. (2004). Ekonomika zemlekorystuvannja ta zemlevporjadkuvannja [Economics of land use and land management] (542 p.). Kyiv: TOV CZRU. (In Ukrainian)

25. Tretiak, A., \& Tretiak, N. (2018). Agricultural lands market in foreighm countries and in Ukraine: the problems of prices and of institutional environment. Land Management, Cadastre and Land Monitoring, 1, 72-80. (In Ukrainian). http://dx.doi.org/10.31548/zemleustriy2018.01.008

26. USDA (2020). Statistics by Subject. Retrieved from https://www.nass.usda.gov/Statistics_by_Subject/Economics_and_Prices/index.php

27. Zos-Kior, M. (2015). Udoskonalennia systemy upravlinnia zemelnymy resursamy ahrarnykh pidpryiemstv v umovakh hlobalizatsii [Improvement of the land management system in the conditions of globalization] (334 p.). Poltava: PNTU. (In Ukrainian). Retrieved from http:// reposit.nupp.edu.ua/handle/PoltNTU/330 